\title{
5 \\ Indigenous Biosecurity: Māori Responses to Kauri Dieback and Myrtle Rust in Aotearoa New Zealand
}

\author{
Simon Lambert, Nick Waipara, Amanda Black, \\ Melanie Mark-Shadbolt and Waitangi Wood
}

\section{Introduction}

The New Zealand economy relies predominantly on the primary sector, which contributes over $50 \%$ of the country's total export earnings and accounts for over 7\% of GDP (New Zealand Treasury 2012). Being an Island nation in the South West Pacific, New Zealand's native flora and fauna are highly endemic, many having evolved in isolation over 65 million years. Both GDP and the conservation of native flora and fauna are dependent on having manageable levels of pests and diseases, something that is becoming increasingly difficult with the unprecedented levels of global movements of materials and people (McGeoch et al. 2010). Despite biosecurity issues being critical to New Zealand's

\footnotetext{
S. Lambert $(\square)$

Department of Indigenous Studies, University of Saskatchewan, Saskatoon, Canada

N. Waipara

Auckland Council, Kauri Dieback Programme, Auckland, New Zealand 
biological heritage, policy and management systems have yet to realise and embed the priorities of Māori who are theoretically the government's formal partner since the signing of the Treaty of Waitangi in 1840.

There are a growing number of cases in New Zealand where Indigenous Knowledge (IK) contests mainstream science for recognition, support and implementation, although the implementation of this is still problematic (see Prussing and Newbury 2016). In New Zealand, Māori-sourced IK, referred to as mātauranga Māori, has an increasingly important role in environmental management, including protection of biological heritage from biosecurity risks and threats. This chapter discusses two case studies of collaboration between Māori and non-Māori in the biosecurity space, resulting in (some) empowerment of Māori and more efficient biosecurity strategies and programmes.

This chapter proceeds with Mead's (2003) all-encompassing definition of mātauranga Māori as Māori knowledge and philosophy, thus allowing a contrast with 'Western' science and philosophy. It is acknowledged that both these philosophical bases (mätauranga Mãori being one of many examples of IK) are dynamic and expanding. Màtauranga Mãori also has an intimate connection to Kaupapa Mãori (Māori methodology) as both a means to progress research with Māori (Smith 1999; Cunningham 1998) and as the fundamental expression of Māori culture within mainstream research (Pihama et al. 2002). We position Kaupapa Mãori as an array of research principles for engaging with Māori in, for example, protecting kauri and other species valued by Māori. These principles are, of course, not limited to Māori-focused research and could be said to be fundamental to any research that relies on human participants (see, e.g. Piddington 1960; Whyte 1981). The justification for professional (and therefore ethical) acknowledgement

\footnotetext{
A. Black - M. Mark-Shadbolt

Bio-Protection Research Centre,

Lincoln University, Lincoln, New Zealand

W. Wood

Tangata Whenua Rōpū, Kauri Dieback Programme, Aotearoa, New Zealand
} 
of Kaupapa Māori (Māori methodology) is that these principles have grown from explicitly localised responses to the perceptions and realities of what Russell Bishop terms 'epistemological racism' (Bishop 1999). The grounding in Māori lives, from the use of Māori words and terms to the social and cultural engagement that occurs specific to Māori people and the spaces that they control, presupposes both the legitimacy of Māori knowledge and methodologies.

This chapter presents two case studies of Indigenous biosecurity action from Aotearoa New Zealand. The first concerns the giant conifer, Agathis australis (New Zealand Kauri), a taonga (treasured, sacred) plant to all New Zealanders and especially for Māori on whose lands these gigantic trees grow. The resilience and health of remnant kauri forests and dependent ecosystems are under increasing threat from the disease phenomenon Kauri Dieback (Phytophthora agathidicida). A seminal joint agency programme that included Māori from governance to community engagement was initiated in 2009. Eight years on this programme is still in existence, although it is yet to realise the potential of Māori knowledge and customs to manage successfully Kauri Dieback.

More successful collaboration has been achieved in the second case study where Māori are involved in extensive efforts to combat the recent incursion of Myrtle Rust (Austropuccinia psidii) which threatens a range of taonga species. Central to this case has been the establishment of a Māori Biosecurity Network that supports the involvement of Māori researchers, governance representatives and political lobbyists.

\section{The Use of Indigenous Knowledge in Forest Conservation and Biosecurity Management}

IK has an as yet unknown value to contemporary forest biosecurity, but such knowledge is increasingly recognised for the opportunities it offers states and jurisdictions that are prepared to accept and resource indigenous participation in this increasingly important and dynamic research area. Given that environmental concerns are increasingly couched in 
terms of political-economic concerns and environmental sustainability, IK discourse represents a convergence of state, corporate and community interests competing for resources in such vital areas as biosecurity. The World Bank has estimated that around 60 million Indigenous peoples are heavily dependent upon forests for their livelihood while an additional 350 million are dependent on them for their income and subsistence (World Bank Group Forest Action Plan FY16-20 2016). Many Indigenous communities will therefore have vested interests in the protection and health of forests, the management of which is mainly subject to a legacy of colonial management.

International literature on Indigenous communities and conservation is dominated by Western paradigms of conservation but includes examples of researchers working alongside and documenting IK for the purpose of gaining insight into aspects of ecology and natural history (Walter and Hamilton 2014; Camara-Leret et al. 2014; de Freitas et al. 2015). Studies examining alternative (including Indigenous) approaches to forest conservation document positive impacts of co-managing forests, including minimising the loss of biodiversity (Souto et al. 2014; Singh et al. 2015). The need for more inclusive approaches to biosecurity research and forest conservation, in partnership with relevant Indigenous communities, is perhaps critical to ensuring the long-term health of many tree species and forest ecosystems such as those found in New Zealand's kauri forests.

\subsection{The Adoption of Māori Knowledge for Forest Conservation}

Māori, like other Indigenous peoples, have developed customary practices to sustainably manage their lands and resources. However, the adoption of mātauranga Māori (Māori knowledge) in mainstream conservation ventures is often limited and mainly focused on the customary harvest of species for food, such as the kereru (New Zealand Wood Pigeon, Hemiphaga novaeseelandiae) and titi (Sooty Shearwater, Puffinus griseus) (Moller et al. 2009; Lyver et al. 2008, 2009), and the customary 
harvest of flax (harakeke in Māori, Phormium tenax) and seaweed, karengo (Bangiaceae spp.) (McCallum and Carr 2012; O'Connell-Milne and Hepburn 2015).

The use of Māori knowledge in New Zealand forest conservation is not particularly visible in research and policy (Walker et al. 2013), and discourse around the use and interpretation of Māori knowledge is often limited to scattered Māori representation in governance roles. While this is an ongoing issue, the longer-term strategic goals of government must expand to include the operationalisation of Māori methods and research priorities in forest health.

\section{The Discovery of Kauri Dieback}

Kauri are an ancient tree species now reduced to a fragment of their pre-colonial habitat and threatened with extinction from an introduced plant pathogen ( . agathidicida) (Waipara et al. 2013). Only recently has the soil-borne pathogen responsible for 'Kauri Dieback' been taxonomically described and named as $P$. agathidicida (Weir et al. 2015). The pathogen initially infects kauri through its roots before progressing to an aggressive collar rot resulting in large basal trunk lesions, then canopy defoliation and eventually death (Bellgard et al. 2016) (Fig. 1). All size and age classes of kauri are susceptible to infection and death. Details on the origin and introduction of Kauri Dieback to New Zealand are still unknown. One hypothesis is that the disease may have initially established through imported seedlings, plant and soil materials from the Oceania region destined for a kauri nursery in Waipoua Forest (Beauchamp and Waipara 2014). It is then thought to have spread to Great Barrier Island and other sites through New Zealand Forest Service plantings from the 1950s, along with secondary spread by domesticated cattle or feral pigs. The initial misidentification as Phytophthora heveae (Gadgil 1974) was corrected by Beever et al. (2009), and the working name 'Phytophthora taxon agathis' or 'PTA' was used up until 2015. The current distribution of Kauri Dieback is shown in Fig. 2. 


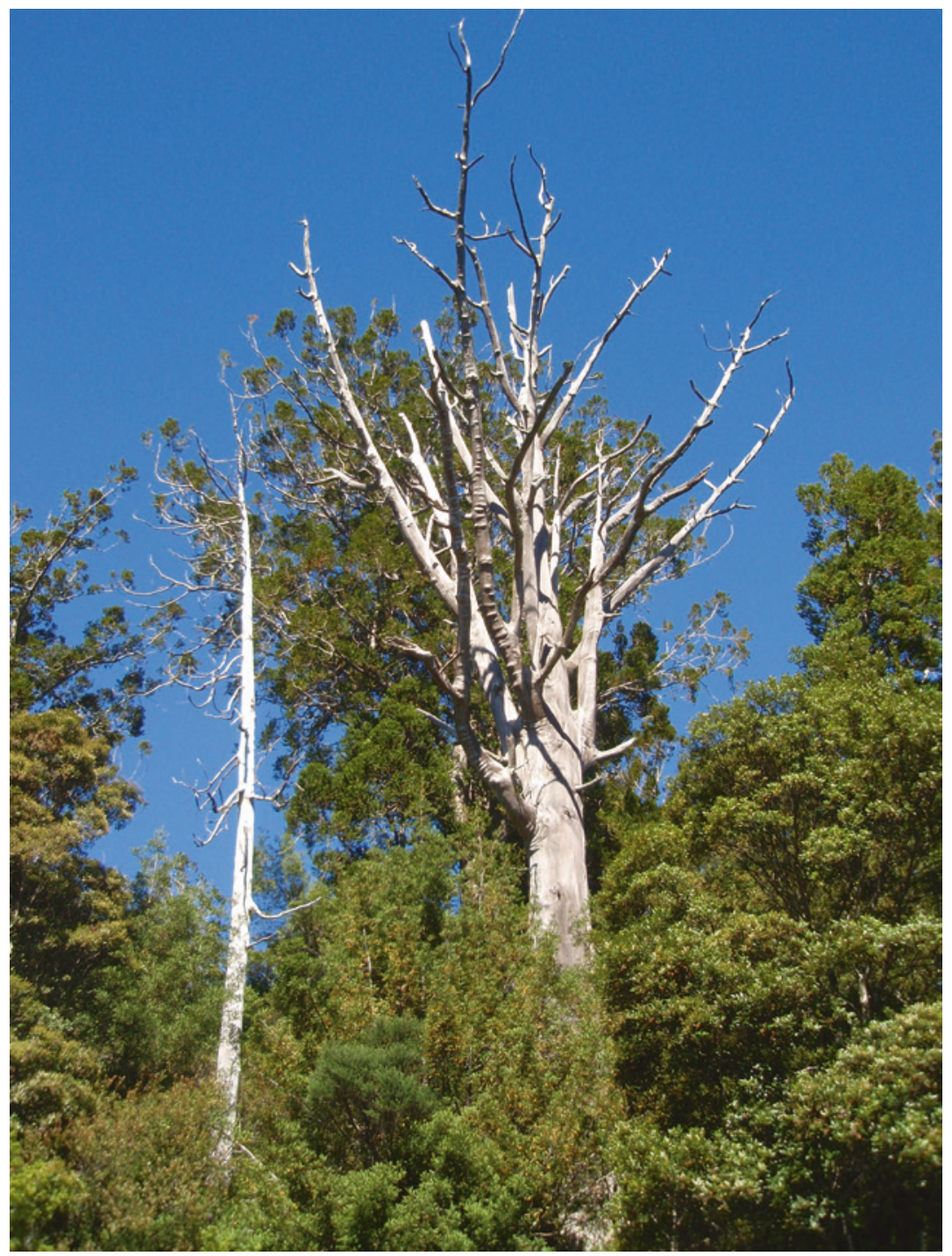

Fig. 1 Dead mature kauri tree $>500$ years old. Commonly referred to as 'stag head' (Source Kauri Dieback Programme, www.kauridieback.co.nz) 


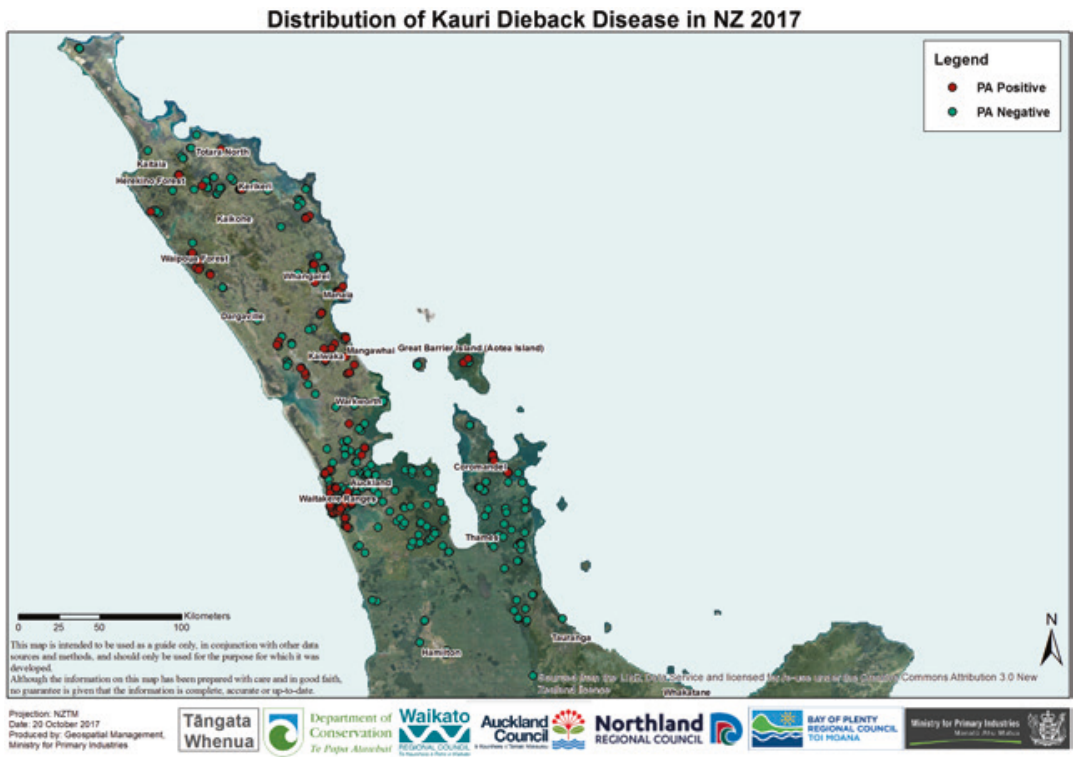

Fig. 2 The distribution of Kauri Dieback disease in New Zealand 2017 (Source Kauri Dieback Programme, www.kauridieback.co.nz/more/where-has-it-beendetected/)

\subsection{Management Strategies for Kauri Dieback}

Human activities, including the transfer of contaminated soils between nurseries, recreational use of kauri forests, and track building and maintenance practices, have been all correlated to the spread and incidence of the disease (Bellgard et al. 2016). Beever et al. (2009) and Horner et al. (2014) demonstrated how susceptible kauri are to infection and how easily infectious propagules, such as oospores, are transmitted from infected to non-infected plants. The pathway of oospore infection is through soil pore water and into the roots of healthy plants; hence, root health and protection of the root zones have a significant effect on the susceptibility of trees to infection (Beauchamp 2013; Waipara et al. 2013). 
In October 2008, Kauri Dieback was declared a pest of national priority (an 'Unwanted Organism') under New Zealand's Biosecurity Act, and a biosecurity response was initiated by MAF Biosecurity New Zealand (now Ministry for Primary Industries), Tangata Whenua (local Māori), Department of Conservation (DoC) and Local Authorities (Regional Councils) within the natural range of kauri (Waipara et al. 2013). In 2009, a long-term management (LTM) programme was implemented to mitigate the disease. As per standard crisis response management models, the early focus was on the pathogen itself, with surveillance programmes set up and containment methods put in place to restrict the movement of soil. These methods are only commonplace on government-owned land and include phytosanitary measures to reduce soil-borne spread, such as footwear wash stations containing Sterigene (a disinfectant), vector control (feral pig and goat eradication), upgrading recreational visitor walking tracks (boardwalks) and closing public access to some high-value kauri areas, including imposing a rāhui (restriction) by local Māori to certain areas (Fig. 3). As of 2017, there is still a lack of measures that can effectively stop the spread of Kauri Dieback which has led to recent recommendations for restricting access and/or closures to threatened kauri forest areas such as the heavily infected kauri stands of the Waitakere Ranges in West Auckland (Hill et al. 2017).

\subsection{Impacts on Māori of Kauri Dieback}

Very few studies exist on the impacts of plant diseases on cultural identity, which highlights the importance of these two case studies. Harris (2006) acknowledges the devastating impact Potato Blight (Phytophthora infestans) had on Māori in 1905-1906, and Beever et al. (2007) identified many potential pre-border pests and diseases that could damage species highly valued by Māori and therefore pose risks of cultural impacts for Māori and their kaitiakitanga (guardianship) roles over particular species (Coffin et al. 2009).

In the case of New Zealand kauri, Nuttall et al. (2010) outline the cultural significance on Māori of the remaining ancient stands of kauri forests. More than $75 \%$ of remaining kauri forests lie within the 


\section{SAVE OUR KAURI FORESTS}

They are dying from kauri dieback disease
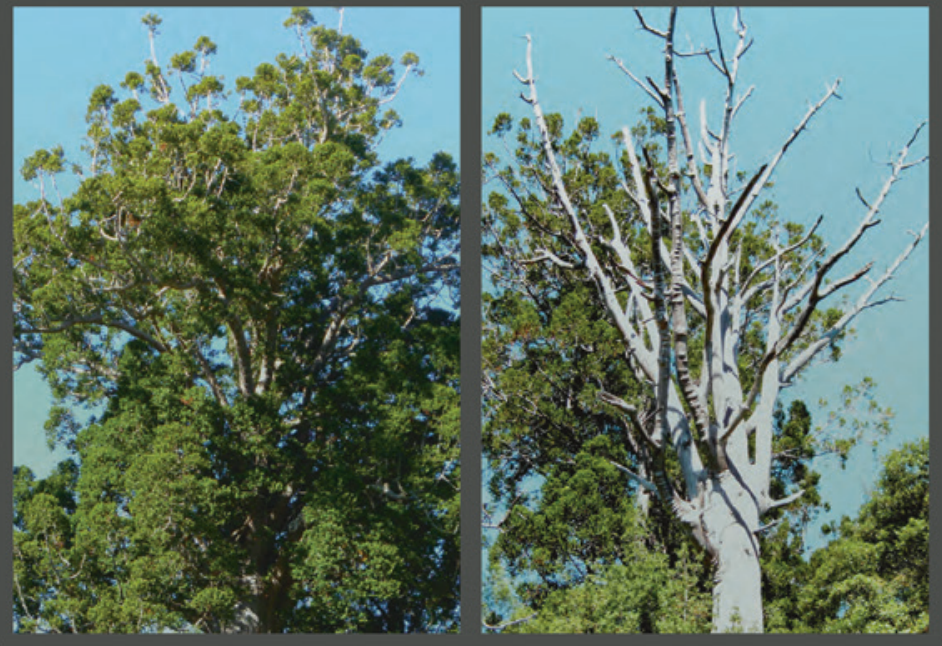

\section{It spreads by soil movement ACT NOW to help stop it}

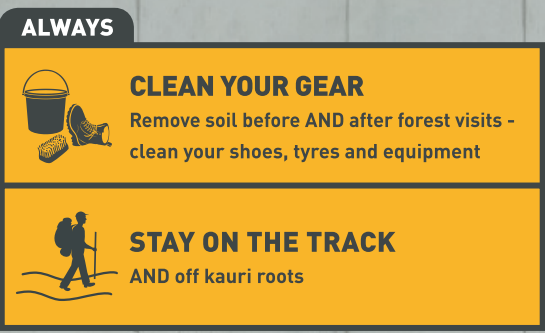

KEEP KAURI STAND NG STOP KaVR DIEBACK OISEASE SPREADING KIA TOITU HE KAURI WWW.KAURIDIEBACK.CO.NZ

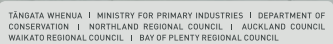

Fig. 3 Signage designed to raise public awareness of Kauri Dieback and the key hygiene measures in place to help reduce the spread of the pathogen (Source Kauri Dieback Programme, www.kauridieback.co.nz) 
Northland region, mostly as fragmented remnants of ancient forests or regenerating successional stands, and for Māori on these territories kauri grow, the tree is the centrepiece of cultural and spiritual beliefs. Of these forests, Waipoua, within Te Roroa tribal lands, is home to the famous 1500-year-old Tāne Mahuta (Fig. 4), standing at 51.5 metres tall and having a girth of 13.8 metres. (Waipoua Forest is also home to the second and third largest kauri). In this territory, local Māori often referred to kauri in speeches, cultural performances and proverbs; the fundamental importance is expressed in the proverb 'Ko te kauri ko au, Ko te au ko kauri - I am the kauri, the kauri is me'.

The health of Waipoua Forests is inextricably linked to by Te Roroa Māori to the mauri (spirit, essence) and mana (respect, authority, status, spiritual power) of their communities, elders and succeeding generations. For Te Roroa, the presence of Kauri Dieback represents yet another negative colonial impact, comparable to the land and population losses of the 1800s where the iwi was essentially landless with little or no resources and struggling to practice traditional concepts.

\subsection{Use of Cultural Health Indicators for Kauri Forest Management}

The application of Māori knowledge for kauri conservation is outlined in three reports: 'Te Roroa Kauri Dieback effects assessment' (Nuttall et al. 2010); 'Kauri dieback cultural indicators' (Shortland 2011), and a report commissioned by the Kauri Dieback Programme (KDP) on kauri cultural health indicators (CHI) (Chetham and Shortland 2013). Both Shortland (2011) and Chetham and Shortland (2013) outline a rationale and framework for Kauri Dieback based entirely on mätauranga Māori, using a holistic approach based on the domains of Atua (spiritual guardians) and recommending the inclusion of the monitoring of other species within the kauri forests; surrounding environmental conditions (soil characteristics, leaf litter, decaying wood detritus); the proximity of significant water bodies, levels of sunlight, human activities; and tree condition. This approach reflects the desire of Indigenous communities to combine selected ecological variables with community 


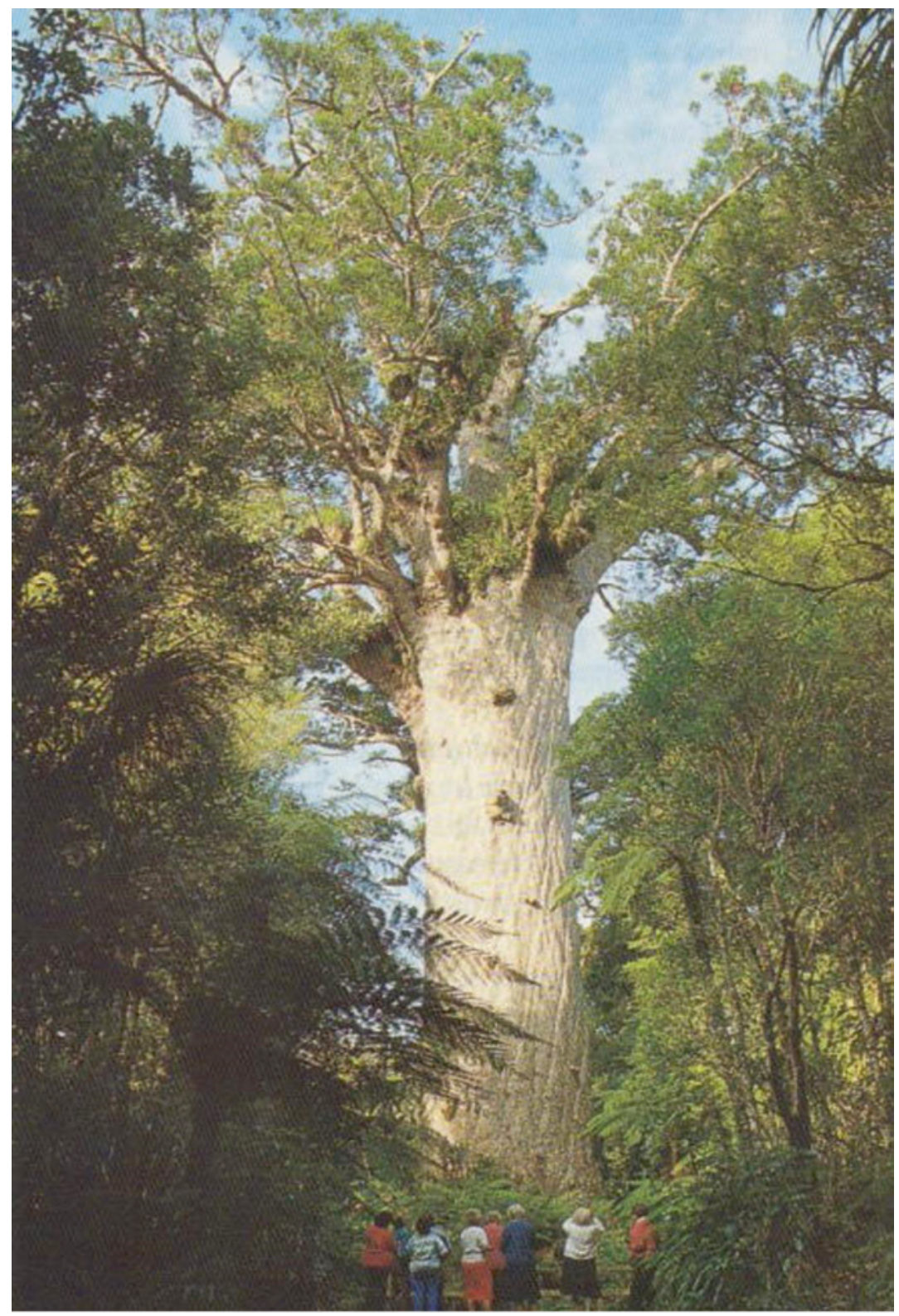

Fig. 4 Tāne Mahuta, Waipoua Forest, Northland, New Zealand (Photograph source Alastair Jamieson, Wild Earth Media, and Auckland Council) 
spiritual experiences of their forests. Attributes such as culturally framed spirituality are difficult for historical academic disciplines to assess within standard scientific ecological impact assessments of trees and, for example, the spread of Kauri Dieback. However, Māori insist that such an approach is essential to capture the wider well-being of their forest systems.

\subsection{The Role of Māori in Managing Kauri Forest Health}

In 2009, prompted by Māori advocacy, central government resourced engagement with Māori communities throughout the kauri districts to determine their role in the newly proposed joint government agency response, the KDP. ${ }^{1}$ This was seen as a significant event in granting partnership status and resulted in a governance and management structure that includes Māori (Fig. 5). This was the first example of a long-term pest management programme attempting to incorporate a partnership model with Māori in New Zealand in accordance with the Treaty of Waitangi.

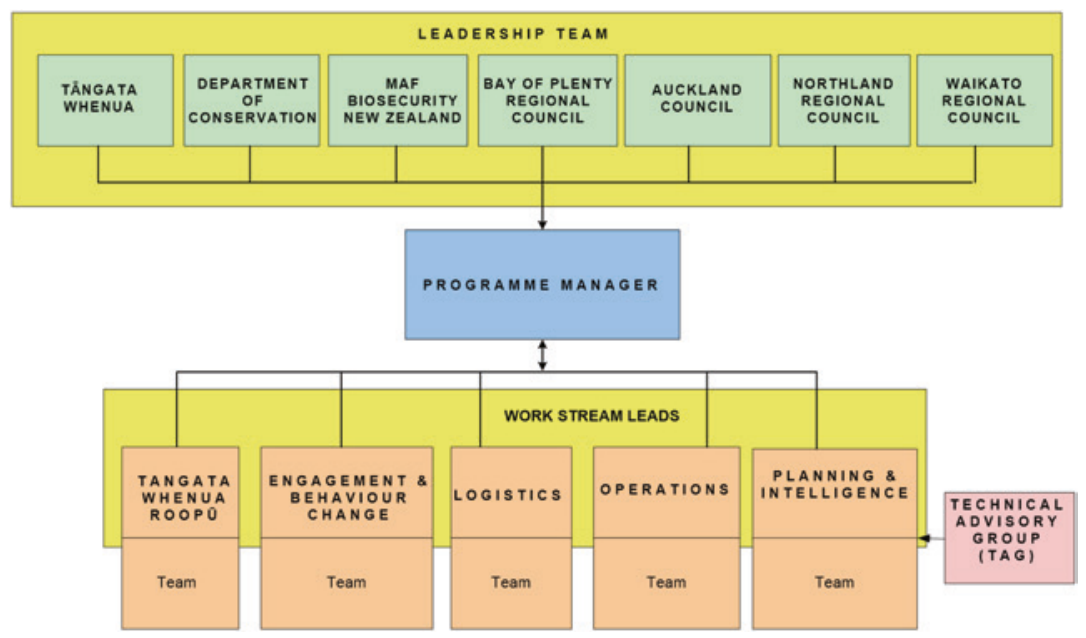

Fig. 5 Governance and management structure for the Kauri Dieback Programme (Source Kauri Dieback Programme, www.kauridieback.co.nz) 
After a series of meetings, participating Māori established the Tangata Whenua Roopu (TWR) as a Māori reference group, comprised of representatives of those Māori whose lands included kauri (Wilson 2009). The TWR determined they would modify current biosecurity management through culturally framed methods and the use of Māori knowledge to manage or resolve the threat of PTA. In addition, the TWR committed to ensuring effective engagement in the PTA long-term management (LTM) plan, aiming to have local Mãori continue to manage PTA beyond the LTM conclusion. At the outset, TWR expressed their expectation that Māori knowledge was fundamental to resolving Kauri Dieback management. In support of the purpose articulated by the TWR, programme partners ${ }^{2}$ recognised the TWR as a key partner. They also formally acknowledged Māori as kaitiaki, guardians, of kauri and as landowners in their own right.

In April 2010, the TWR commissioned as part of its focus a cultural impact assessment on kauri (Chetham and Shortland 2013). It was also determined that the KDP programme would include increasing the capability of Māori in additional management-related activities such as surveillance, long-term monitoring and research. The TWR has representation in operations (operational management of Kauri Dieback); planning and intelligence (informing the programme with technical expertise and underpinning science); and engagement and behaviour change (including communication, media, public awareness and compliance with programmes key messaging). This model is the first case in which Māori have been represented at all levels of a management programme, and this has been captured in the KDP programmes Strategic Overview Goal Two (Ministry for Primary Industries, n.d.-a), 'Building Knowledge and Tools', in which Māori knowledge was embedded. The goal was then to harmonise mainstream science with mätauranga Māori through a plan that identified: (1) how mātauranga Māori (Māori knowledge) research, tools and monitoring will be implemented; (2) priority knowledge gaps that needed to be addressed; (3) how advice from experts will be obtained and utilised; and (4) arrangements to provide assurance and demonstrate that scientific evidence and analysis are sought, obtained, interpreted, used and communicated appropriately within the programme (ibid., p. 17). The expected benefits of 
implementing these goals include greater confidence that Māori would be harnessing the right advice and that decision-making is founded on robust scientific and cultural knowledge; enhanced knowledge of how to manage Kauri Dieback is obtained; and knowledge is gained from and used by those who are guardians of kauri.

The commissioning of a cultural impact assessment has helped initiate the operationalisation of Māori knowledge in the KDP, including the development of a Kauri Cultural Health Index and potential sites to pilot these indices for the detection of Kauri Dieback. The KDP has included funding specifically for the development of forest health indicators using Māori knowledge, with three broad areas of scientific and community interest chosen: Ngahere (forest), Oneone (earth, soil) and Water (wai). The model has the potential to produce successful synergistic social and conservation benefits for kauri forests.

However, these efforts to introduce an IK base into contemporary forest biosecurity were met with strong resistance and a general lack of recognition by some forestry managers and agencies. A change in membership and leadership has seen the programme delayed. Frustration for participating Māori and missed opportunities for better biosecurity outcomes describe the Indigenous experience in this case, although participants are continuing to advocate for future opportunities to ensure the status of Māori knowledge in New Zealand forest management.

\section{The Māori Biosecurity Network: Te Tira Whakamātaki (TTW)}

Informed by the experiences of Māori trying to address Kauri Dieback and aware of the continuing absence of a Māori voice in wider biosecurity issues, a group of Māori researchers travelled around New Zealand in 2015 and 2016 and met with interested individual Māori and collectives whose interests were across a range of commercial and environmental sectors. With funding from the Ministry of Business, Employment and Innovation (MBIE) and New Zealand's Biological Heritage National Science Challenge (NZBHNSC) discussions took 
place on the necessity for a national network that could focus on the need for Māori to have a voice in the biosecurity system. At these meetings, Kauri Dieback was presented as an existing biosecurity threat, and Myrtle Rust was used as an exemplar of a disease that would likely prove to be a biosecurity threat at some point in the near future (Te Tira Whakamātaki 2017; NZ Biological Heritage National Science Challenge, n.d.-a, b).

An important aim of these hui (meetings) was to engage with Māori pre-incursion and to develop processes to frame effective responses to current and future incursions based in large part on Māori knowledge. Additionally, the network wanted to make better use of data, including data sourced by or from Māori, and the insights and experiences of participating Māori, many of whom had established networks vital for understanding and combating the threats of pests and diseases affecting Māori bio-cultural interests.

The Māori Biosecurity Network has been vocal in their concern about the exclusion of Māori from the biosecurity system in New Zealand, as well as the existence of multiple strategies across several Ministries that overlap and are reactive, creating additional costs in administration and management and duplication. The network argues that 'Māori are in the best position to remind Ministries and agencies that a holistic view to fixing our biodiversity issues needs to be taken' (Mark-Shadbolt 2017a). The important role of the Māori Biosecurity Network in organising and overseeing a Māori response to a significant biosecurity incursion is discussed next.

\section{The Discovery of Myrtle Rust in New Zealand}

Myrtle Rust ( $A$. psidii) is a devastating fungal plant disease. It is indigenous to South and Central America and the Caribbean (Teulon et al. 2015) but has spread to many other regions, including New Guinea and Australia, where it is threatening the extinction of several plant species of significance to Aboriginal Australians (Robinson et al. 2016). It was discovered in Hawai'i in 2005 and has since devastated 
the 'Ōhi'a tree which is an important species for native Hawaiians (Uchida et al. 2006). Since its arrival in Australia in 2010, its host range has doubled to over 346 known Myrtle Rust hosts globally, and at least nine native New Zealand Myrtaceae species that are cultivated in Australia have been confirmed as being infected (Teulon et al. 2015). Myrtle Rust spores can easily spread large distances by wind and can also be transported on clothing, equipment, insects, rain splashes and probably also cyclones. Impacts of the pathogen have ranged from superficial temporary infections to devastating outbreaks.

The first identification of Myrtle Rust in a New Zealand territory was on Raoul Island (Rangitahua), part of the Kermadec Island group situated a thousand kilometres north of the mainland's North Island. At the time, the newly established Māori Biosecurity Network released a press statement in which they argued, 'as [Myrtle Rust] has now reached our outer islands, we need to be vigilant and we need a plan' (Te Tira Whakamātaki 2017). The Network also offered their support and their knowledge (mätauranga) to the Ministry for Primary Industries (MPI) and DoC to help with the response (Te Tira Whakamātaki 2017). The offer was made because while the severity of the disease's effects in New Zealand was unknown, what was known was the disease's likelihood to infect native New Zealand Myrtaceae species.

Since that initial discovery on Raoul Island (Rangitahua), Myrtle Rust has been discovered in mainland New Zealand, initially in Northland in May of 2017, and then further south in Waikato, Taranaki, Auckland and Te Puke (Ministry for Primary Industries 2017).

\subsection{The Impacts of Myrtle Rust on Māori}

Indigenous Myrtaceae species utilised by Māori for medicine, construction and food, and that are susceptible to Myrtle Rust, include kānuka (Kunzea ericoides), mānuka (Leptospermum scoparium), ramarama (Lophomyrtus bullata), rohutu (Lophomyrtus obcordata) and various rātā species (Metrosideros spp., particularly M. excelsa, the pōhutukawa or New Zealand Christmas Tree). Other introduced species which Māori utilise, such as feijoa (Acca sellowiana) and several eucalyptus varieties (Eucalyptus spp.), may also be vulnerable (Teulon et al. 2015). 
Māori have increasing commercial interests in mānuka honey, pharmaceuticals and cosmetics, and the loss of flowers and new growth could potentially have significant implications for these industries (Teulon et al. 2015).

Honey production for both pōhutukawa and mānuka may be significantly affected in terms of both productivity and quality. Similarly, the quality of medicinal (traditional/rongoa and modern) products from key species may also be compromised. Impacts in this area may very much depend on which elite honey and medicinal plant biotypes are affected by Myrtle Rust. (Teulon et al. 2015, p. 70)

While the future distribution and impacts of Myrtle Rust are relatively unknown, it can be assumed that all Myrtaceae species in New Zealand are at risk and the impacts could be devastating. However, the potential sociocultural consequences for Māori are yet to be fully understood or addressed.

\subsection{Management Strategies for Myrtle Rust}

The current New Zealand government strategy for managing the spread of Myrtle Rust is focused on identifying outbreaks, spraying infected plants to halt the spread of the disease, removing infected plants and then burying them (Ministry for Primary Industries 2017). A Technical Advisory Group (TAG) made up of science experts and industry representatives was established to support the Ministry of Primary Industries to make decisions around the response; the Australian members of the group delivered a strong message to New Zealand: aim for eradication. However, with the increasing number of finds, it is anticipated that central government will move the Myrtle Rust response into one of LTM. The focus will then shift from eradication to long-term management, and central government's efforts and resourcing will be diverted to research and management.

The Māori Biosecurity Network, guided by iwi (tribes), hapū (subtribes) and whānau (individual Māori families), believed strongly in aiming for eradication of the disease and argued that Māori kaitiaki 
(as local environmental guardians) were the best 'eyes on the ground', and with their community, networks were 'best placed to identify the first signs of the disease on mainland Aotearoa' (Te Tira Whakamātaki 2017). The Network believed that eradication and containment, even if only regionally, were achievable if Māori knew how to recognise Myrtle Rust, report suspected discoveries in a timely manner and were allowed to be involved in the strategies designed to halt the spread (Te Tira Whakamātaki 2017). Additionally, the Network has argued for greater engagement with Māori at all levels, noting that a failure to properly engage will create tensions and hinder an effective long-term response. Evidence of this tension was reported on Radio New Zealand by McSweeny (2017) who noted iwi members were heavily critical of the way the ministry engaged with them over the incursion and voiced their condemnation at the Thursday meeting to MPI officials'.

At the time of publishing, the Māori Biosecurity Network was continuing to offer support to researchers and government agencies in the development of management strategies (Te Tira Whakamātaki 2017). However, despite support from numerous research organisations, there has been little uptake from either MPI or DoC, the two key government agencies. Accordingly, the Māori Biosecurity Network has been forced to develop its own Myrtle Rust management strategy. The Network's strategy is based on the articulated aspirations of over 300 Māori they consulted with between May and October 2017. The Network's response to those aspirations is discussed next.

\subsection{The Use of Cultural Health Indicators and the Role of Māori in Managing Vulnerable Species and Ecosystems}

One of the founding motivations for establishing the Māori Biosecurity Network was that the inclusion of Māori in biosecurity management was important because if Māori were informed by the latest research about incoming pests and diseases they would be better prepared, more easily mobilised and able to take an active role in the protection of the species and sites of significance to them. This view, which is a 
very traditional role, was also evident in the Māori response to Kauri Dieback. In both cases, Māori expressed a desire for tools based on their knowledge and for surveillance training and accreditation to be developed. Additionally, they have requested that the proprietary rights of Māori over particular plants and plant materials be considered and protected. In particular are concerns at the lack of, or ad hoc, engagement by agencies collecting seeds and germplasm 'under urgency' (for ex situ preservation and conservation of susceptible plants) without robust prior cultural safety agreements with local tribes.

While, in the Kauri Dieback space, Māori have and continue to struggle to get Māori management strategies recognised, resourced and/or implemented, the Māori Biosecurity Network achieved quick successes in the implementation of responses to Myrtle Rust. Within five months of the first mainland incursion, the Māori Biosecurity Network had trained over 100 kaitiaki to identify Myrtaceae plants and Myrtle Rust, and report suspected Myrtle Rust finds. They, along with other partners, had also released a smartphone application that also assisted in the identification of both Myrtaceae species and Myrtle Rust, while providing a platform for live reporting of suspected finds (New Zealand's Biological Heritage National Science Challenge, n.d.-a, b).

The incorporation of màtauranga Mãori in the response to Myrtle Rust, while better than Kauri Dieback, has been limited to date. The approach by government has mainly been one of engagement, and the development of CHI is still at an early stage. However, kaitiaki (guardians) are already developing indicators or ideas on how to mitigate the effects of the disease; for example, they have expressed a desire to plant ramarama (Lophomyrtus bullata) either near sites of significance to take the brunt of the infection, or close by as sentinels. More time and resourcing are needed to find and refine further indicators.

\section{Discussion}

The special relationship that mana whenua (local Māori) have with kauri was recognised with the inception of the KDP in 2010, a joint agency response that included central government, regional agencies 
and Māori community groups. This was the first 'true' partnership between Māori and government, as per the expectations of the Treaty of Waitangi, which was established to manage any biosecurity incursion but particularly the devastating impacts of $P$. agathidicida on kauri forests.

In trying to address Kauri Dieback, Māori have struggled in their attempts to collaborate with researchers and government officials, both local and national. By arguing for a new role in biosecurity management which would integrate Māori knowledge in any effort to understand and combat the disease, local Māori and their supporters found themselves challenged by mainstream scientists and regulators. So far, only Western-style management methods have been implemented: phytosanitary measures to reduce soil-borne spread; vector control; upgrading walking tracks; and closing public access to some areas. Research outside of the programme is underway on how scientists can better collaborate with IK holders to produce solutions to mitigate the effects of Kauri Dieback.

The 2017 arrival of Myrtle Rust poses a significant threat to several native plants including culturally and commercially significant species such as manuka (Leptospermum scoparium), source of the highly lucrative mānuka honey (Department of Conservation 2017). The near-cotemporaneous establishment of Te Tira Whakamātaki, as a Māori-centric 'network of the willing' (Mark-Shadbolt 2017a), was fortuitous. With members including Māori researchers and wider support from mainstream allies, the network has both scientific and political credibility. It is important to note that Te Tira Whakamātaki receives no direct funding but instead leverages off the existing research and programmes of its Executive; indeed, the leadership made a conscious decision not to accept money or contracts unless it was very clear about the purpose of that funding (Mark-Shadbolt 2017b). Their argument has been that by accepting money from the government results in government assuming the right to dictate or control the conversations, results, data generation and measures of success; at least two government agencies were accused of claiming Te Tira Whakamātaki events (community meetings) as their own achievements. 
Te Tira Whakamātaki, the Māori Biosecurity Network, has argued that Māori roles of environmental guardianship are the best option to access the forests efficiently and with minimal disturbance to other species. As government officials and agents are not undertaking extensive surveillance in the wild, it is often only these kaitiaki who also know the sites of significance that need to be inspected and observed. This saves costs, ensures sufficient geographical coverage, secures Māori their rightful role as Treaty partners and supports Māori aspirations for their economic, environmental and cultural well-being.

Worldwide, there are undoubtedly many other biosecurity events that would benefit from local IK and the empowered participation of Indigenous representatives and their communities. Researchers, officials and the private sector must take seriously the rights of Indigenous peoples to determine their self-development and elevate the ethical engagement with Indigenous communities as a priority in the biosecurity of the world's forests.

\section{Concluding Summary}

The implementation of alternative models of partnership with Indigenous communities as demonstrated by the KDP and Te Tira Whakamātaki has resulted in the involvement of Indigenous representatives across research governance, strategy and field operations. In this chapter, we have argued that the adoption of IK and indigenous practices and the empowered participation of Indigenous environmental managers and their communities are vital for the sustainable management and long-term protection of many of the world's forests. In Aotearoa New Zealand, the inclusion of kaitiaki (Māori guardians) and the adoption of Māori practices such as kaitiakitanga (guardianship) can enhance and inform the long-term protection of kauri ecosystems and Myrtaceae species across the country. Such a collaborative approach provides efficiencies in national and local biosecurity strategies and tactics and, importantly, enables the fulfilment of Indigenous aspirations of economic, environmental and cultural well-being. 


\section{Acronyms}

DoC Department of Conservation

CHI Cultural Health Indicators

KDP Kauri Dieback Programme

LTM Long-Term Management

MAF Ministry of Agriculture \& Fisheries, now MPI

MBIE $\quad$ Ministry for Business, Innovation \& Employment

MPI Ministry for Primary Industries: Manatū Ahu Matua

NZBHNSC New Zealand's Biological Heritage National Science Challenge

PTA Phytophthora Taxon Agathis

RMA Resource \& Management Act 1993

TAG Technical Advisory Group

TTW Te Tira Whakamātaki, the Māori Biosecurity Network

TWR Tangata Whenua Roopu

\section{Glossary}

Atua

Spiritual guardians, gods

Hapū

Harakeke

Subtribe, extended family group

Hui

Iwi

Kaitiaki

Kaitiakitanga

Kānuka

Flax, Phormium tenax

Karengo

Kauri

Kaumātua

Meetings

Tribe

Kererū

Guard, guardian, caretaker, manager, trustee

Guardianship

Kunzea ericoides

Edible seaweed (Bangiaceae sp.)

Agathis australis

Elder

New Zealand Wood Pigeon (Hemiphaga novaseelandiae)

Kaupapa Māori Māori methodology

Mana

Respect, authority, control, power, status, spiritual power 
Mana whenua

Mānuka

Māori

Mātauranga

Mātauranga Māori

Mauri

Ngahere

Oneone

Pōhutukawa

Rahui

Ramarama

Rangitahua

Rātā

Rohutu

Tangata whenua

Tāne Mahuta

Tangata Whenua Roopu Taonga

Te Roroa

Te Tira Whakamātaki

Tìt $\overline{1}$

Treaty of Waitangi

Wai
Local Māori with territorial rights and cultural authority over land

Leptospermum scoparium

Word used to describe the Indigenous people of New Zealand

Information, knowledge, education

Māori knowledge

Life principle

Forest

Earth, soil

M. excelsa or the New Zealand Christmas Tree

Exclusion, ban, quarantine

Lophomyrtus bullata

Raoul Island, part of Kermadec Island group $1000 \mathrm{~km}$ north of New Zealand

Metrosideros spp., particularly $M$. excelsa, the pōhutukawa or New Zealand Christmas Tree Lophomyrtus obcordata

Local people, aborigine, native

God (guardian spirit) of the forest and name of largest Kauri tree in New Zealand

Māori community group(s)

Treasured, sacred property

A Māori tribe from the region between the Kaipara Harbour and the Hokianga Harbour in Northland, New Zealand The Māori Biosecurity Network (translates as the vigilant or watchful ones)

Muttonbird

Treaty signed between the representatives of the British Crown and Māori tribal leaders in 1840 .

Water 
Whakapapa

Whānau

Genealogy, cultural identity, ancestry (extends to species assemblages within a holistic ecosystem paradigm)

Immediate family, also used by Māori to describe individual Māori

Acknowledgements Nga mihi and thanks to Lincoln University for sponsoring this chapter's open access status.

\section{Notes}

1. Previously the Kauri Dieback Joint Agency Response, until 2015 when the name of Programme was changed to first the Kauri Dieback Management Programme to reflect the Ministry for Primary Industries (MPI) declaring PTA an unwanted organism (UO) in 2008 under New Zealand's Biosecurity Act (1993), thus initiating a central government response to assess future management options. In 2009, a five-year long-term management programme was implemented. MPI's priority from 2009 to 2014 was to manage Kauri Dieback as opposed to eradicating Kauri Dieback.

2. Auckland Regional Council, Waikato Regional Council, Northland Regional Council, Ministry of Agriculture and Fisheries, Department of Conservation.

\section{References}

Beauchamp, A. J. (2013). The detection of Phytophthora Taxon "Agathis" in the second round of surveillance sampling - With discussion of the implications for kauri dieback management of all surveillance activity. Client report: Joint Agency Kauri Dieback Response. http://www.kauridieback.co.nz/ media/34150/surveillance\%202\%20final\%20report\%20pdf.pdf (Accessed March 21, 2016).

Beauchamp, T., \& Waipara, N. (2014). Surveillance and management of kauri dieback in New Zealand. In Proceedings of the 7th Meeting of the International Union of Forest Research Organizations (IUFRO), Working Party S07-02-09, Phytophthora in Forests and Natural Ecosystems (p. 142). November 10-14, Esquel, Argentina. 
Beever, R. E., Harman, H., Waipara, N., Paynter, Q., Barker, G., \& Burns, B. (2007). Native flora biosecurity impact assessment (Landcare Research Contract Report LC0607/196). For MAF Biosecurity New Zealand, Volume 1 (103 pp), Volume 2 (202 pp).

Beever, R. E., Waipara, N. W., Ramsfield, T. D., Dick, M. A., \& Horner, I. J. (2009). Kauri (Agathis australis) under threat from Phytophthora? In Proceedings of the Fourth Meeting of the International Union of Forest Research Organizations (IUFRO) Working Party S07-02-09. Phytophthoras in Forests and Natural Ecosystems, August 26-31, Monterey, CA, USA.

Bellgard, S. E., Pennycook, S. R., Weir, B. S., Ho, W., \& Waipara, N. W. (2016). Phytophthora agathidicida. Forest Phytophthoras, 6(1). https://doi. org/10.5399/osu/fp.5.1.3748.

Bishop, R. (1999). Kaupapa Māori Research: An indigenous approach to creating knowledge. Paper presented at the Māori Psychology: Research and Practice, Hamilton.

Camara-Leret, R., Paniagua-Zambrana, N., Balslev, H., Barfod, A., Copete, J. C., \& Macia, M. J. (2014). Ecological community traits and traditional knowledge shape palm ecosystem services in northwestern South America. Forest Ecology and Management, 334, 28-42. https://doi.org/10.1016/j. foreco.2014.08.019.

Chetham, J., \& Shortland, T. (2013). Kauri cultural health indicators: Monitoring framework. Unpublished report prepared by Repo Consultancy Ltd for the Kauri Dieback Programme.

Coffin, A., van Eyndhoven E., \& Beever, R. E. (2009). Native flora impact assessment (MAF Biosecurity New Zealand Technical Paper No. 2009/32). ISBN 978-0-478-35185-9 (31 pp).

Cunningham, C. (1998). A framework for addressing Maori knowledge in research, science and technology. Te Oru Rangahau Maori Research and Development Conference, Massey University.

de Freitas, C. T., Shepard, G. H., Jr., \& Piedade, M. T. F. (2015). The floating forest: Traditional knowledge and use of Matupá vegetation islands by riverine peoples of the Central Amazon. PLoS One, 10(4), e0122542. https:// doi.org/10.1371/journal.pone.0122542.

Department of Conservation. (2017). Biosecurity Alert Myrtle Rust, Austropuccinia psidii. Wellington: Department of Conservation.

Gadgil, P. D. (1974). Phytophthora heveae, a pathogen of kauri. New Zealand Journal of Forestry Science, 4, 59-63. 
Harris, G. (2006). Te Paraiti: The 1905-1906 potato blight epidemic in New Zealand and its effects on Mãori communities. Retrieved from https://repository.openpolytechnic.ac.nz/handle/11072/1212.

Hill, L., Stanley, R., Hammon, C., \& Waipara, N. (2017). Kauri Dieback Report 2017: An investigation into the distribution of Kauri Dieback, and implications for its future management, within the Waitakere. Ranges Regional Park, Auckland Council Technical Report. Version 2: Update June 2017 (40 pp).

Horner, I. J., Hough, E. G., \& Zydenbos, S. M. (2014). Pathogenicity of four Phytophthora species on kauri: In vitro and glasshouse trials. New Zealand Plant Protection, 67, 54-59.

Lyver, P. O., Taputu, T. M., Kutia, S. T., \& Tahi, B. (2008). Tuhoe Tuawhenua matauranga of kereru (Hemiphaga novaseelandiae novaseelandiae) in Te Urewera. New Zealand Journal of Ecology, 32(1), 7-17.

Lyver, P. O., Jones, C. J., \& Doherty, J. (2009). Flavor or forethought: Tuhoe traditional management strategies for the conservation of kereru (Hemiphaga novaeseelandiae novaeseelandiae) in New Zealand. Ecology and Society, 14(1), 40.

Mark-Shadbolt, M. (2017a). Biosecurity (Report to Natural Resource Iwi Leaders Group). Lincoln: Te Tira Whakamataki.

Mark-Shadbolt, M. (2017b). Te Tira Whakamātaki: Māori biosecurity network. Crazy \& Ambitious Conference. https://www.youtube.com/ watch?v=T3HgJ2s8OLU.

McCallum, R. E., \& Carr, D. J. (2012). Identification and use of plant material for the manufacture of New Zealand indigenous woven objects. Ethnobotany Research \& Applications, 10, 185-198.

McGeoch, M. A., Butchart, S. H. M., Spear, D., Marais, E., Kleynhans, E. J., Symes, A., et al. (2010). Global indicators of biological invasion: Species numbers, biodiversity impact and policy responses. Diversity and Distributions, 16, 95-108. http://doi.org/10.1111/j.1472-4642.2009.00633.x.

McSweeny, J. (2017). MPI failed to engage over Myrtle Rust-Bay of Plenty iwi. http://www.radionz.co.nz/news/national/337062/mpi-failed-to-engageover-myrtle-rust-bay-of-plenty-iwi.

Mead, H. M. (2003). Tikanga Mãori: Living by Mãori values. Wellington: Huia.

Ministry for Primary Industries. (n.d.). Kia Toitu He Kauri/Keep Kauri Standing. https://www.kauridieback.co.nz/media/1393/kauri-diebackstrategy-2014-final-web.pdf. 
Ministry for Primary Industries. (2017). Myrtle Rust. Retrieved October 19, 2017, from http://www.mpi.govt.nz/protection-and-response/finding-andreporting-pests-and-diseases/pest-and-disease-search?article $=1484$.

Moller, H., Fletcher, D., Johnson, P., Bell, B., Flack, D., Bragg, C., et al. (2009). Changes in sooty shearwater (Puffinus griseus) abundance and harvesting on the Rakiura Titi Islands. New Zealand Journal of Zoology, 36(3), 325-341. https://doi.org/10.1080/03014220909510158.

New Zealand Treasury. (2012). New Zealand economic and financial overview 2012. Wellington: Treasury.

New Zealand's Biological Heritage. (2017). Myrtle Rust reporter [Press release]. Retrieved January 21, 2018, from http://www.biologicalheritage.nz/news/ research-stories/myrtle-rust-reporter.

New Zealand's Biological Heritage National Science Challenge. (n.d.-a). Myrtle Rust Update \#1. http://www.biologicalheritage.nz/programmes/ maori-biosecurity-network/myrtle-rust/update-1.

New Zealand's Biological Heritage National Science Challenge. (n.d.-b). Myrtle Rust Update \#2. http://www.biologicalheritage.nz/programmes/ maori-biosecurity-network/myrtle-rust/update-2.

Nuttall, P., Ngakuru W., \& Marsden, M. (2010). Te Roroa effects assessment for Kauri Dieback disease-(Phytophthora taxon Agathis-PTA). Report prepared for Te Roroa and the Kauri Dieback Joint Agency Response by Wakawhenua.

O'Connell-Milne, S. A., \& Hepburn, C. D. (2015). A harvest method informed by traditional knowledge maximises yield and regeneration post-harvest for karengo (Bangiaceae). Journal of Applied Phycology, 27, 447-454.

Piddington, R. (1960). Action anthropology. Journal of the Polynesian Society, 69(3), 199-213.

Pihama, L., Cram, F., \& Walker, S. (2002). Creating methodological space: A literature review of Kaupapa Māori research. Canadian Journal of Native Education, 26(1), 30-42.

Prussing, E., \& Newbury, E. (2016). Neoliberalism and indigenous knowledge: Māori health research and the cultural politics of New Zealand's "National Science Challenges". Social Science \& Medicine, 150, 57-66. https://doi.org/10.1016/j.socscimed.2015.12.012.

Robinson, C. J., Maclean, K., Hill, R., Bock, E., \& Rist, P. (2016). Participatory mapping to negotiate indigenous knowledge used to assess environmental risk. Sustainability Science, 11(1), 115-126. 
Shortland, T. (2011). Cultural indicators for Kauri Ngahere. A report prepared for the Tangata Whenua Roopu. Kauri Dieback Joint Agency Response, Whangarei, New Zealand.

Singh, R. K., Srivastava, R. C., Pandey, C. B., \& Singh, A. (2015). Tribal institutions and conservation of the bioculturally valuable 'tasat' (Arenga obtusifolia) tree in the eastern Himalaya. Journal of Environmental Planning and Management, 58(1), 69-90. https://doi.org/10.1080/09640568.2013.847821.

Smith, L. T. (1999). Decolonizing methodologies: Research and indigenous peoples. Dunedin: University of Otago Press.

Souto, T., Deichmann, J. L., Nunez, C., \& Alonso, A. (2014). Classifying conservation targets based on the origin of motivation: Implications over the success of community-based conservation projects. Biodiversity and Conservation, 23(5), 1331-1337. https://doi.org/10.1007/s10531-014-0659-9.

Te Tira Whakamātaki. (2017). Myrtle Rust position statement. Lincoln: Maori Biosecurity Network/Te Turi Whakamataki.

Teulon, D. A. J., Alipia, T. T., Ropata, H. T., Green, J. M., Viljanen-Rollinson, S. L. H., Cromey, M. G., et al. (2015). The threat of Myrtle Rust to Māori taonga plant species in New Zealand. New Zealand Plant Protection, 68, 66-75.

Uchida, J., Zhong, S., \& Killgore, E. (2006). First report of a Rust disease on Ohia caused by Puccinia psidii in Hawaii. Plant Disease, 90(4), 524. https:// doi.org/10.1094/PD-90-0524C.

Waipara, N. W., Hill, S., Hill, L. M. W., Hough, E. G., \& Horner, I. J. (2013). Surveillance methods to determine tree health, distribution of Kauri Dieback disease and associated pathogens. New Zealand Plant Protection, 66, 235-241.

Walker, D., Ataria, J., Hughey, K., \& Lambert S. (2013). Developing a culturally-based environmental monitoring and assessment tool for New Zealand Indigenous forests. 19th International Symposium on Society and Resource Management. June 4-8, Estes Park, CO, USA.

Walter, R. K., \& Hamilton, R. J. (2014). A cultural landscape approach to community-based conservation in Solomon Islands. Ecology and Society, 19(4), 41. https://doi.org/10.5751/ES-06646-190441.

Weir, B. S., Paderes, E. P., Anand, N., Uchida, J. Y., Pennycook, S. R., Bellgard, S. E., \& Beever, R. E. (2015). A taxonomic revision of Phytophthora Clade 5 including two new species, Phytophthora agathidicida and P. cocois. Phytotaxa, 205(1), 21-38.

Whyte, W. F. (1981). Street corner society: The social structure of an Italian slum. Chicago and London: University of Chicago. 
Wilson, S. (2009). Kauri Dieback (Phytophthora taxon Agathis) Joint Agency Response: Tāngata Whenua Hui. Summary Report (Unpublished), Maximise Consultancy (66 pp).

World Bank Group. (2016). World Bank Group Forest Action Plan F1620. Washington, DC. Retrieved from http://documents.worldbank.org/ curated/en/240231467291388831/Forest-action-plan-FY16-20.

Open Access This chapter is licensed under the terms of the Creative Commons Attribution 4.0 International License (http://creativecommons. org/licenses/by/4.0/), which permits use, sharing, adaptation, distribution and reproduction in any medium or format, as long as you give appropriate credit to the original author(s) and the source, provide a link to the Creative Commons license and indicate if changes were made.

The images or other third party material in this chapter are included in the chapter's Creative Commons license, unless indicated otherwise in a credit line to the material. If material is not included in the chapter's Creative Commons license and your intended use is not permitted by statutory regulation or exceeds the permitted use, you will need to obtain permission directly from the copyright holder.

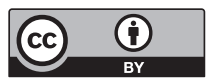

